\title{
ФОРМУВАННЯ ЛОЯЛЬНОСТІ ПЕРСОНАЛУ В УМОВАХ КОНЦЕПЦІЇ ВНУТРІШНЬОГО МАРКЕТИНГУ
}

\author{
Богоявленський О. В., к.е.н., доцент (ХІФ КНТЕУ)
}

У статті наведені результати дослідження стану лояльності персоналу підприємств різних сфер діяльності м. Харкова, визначені підприємства, на яких переважає висока стабільність штату працівників, знайдені ключові фактори, які сприяють тривалій прачі співробітників на одному місиі. Проведений критичний аналіз різних тлумачень поняття «лояльність персоналу». Запропонована власна трактовка поняття класифікації типів лояльності співробітників. Проаналізовані теоретико-методологічні підходи стосовно оцінки потенційної лояльності робітників i кандидатів на вакантні робочі місия. Розроблені пропозииї по застосуванню програм лояльності в рамках системи внутрішнього маркетингу. Розглянуті основні головні елементи і особливості комплексу внутрішнього маркетингу підприємства та його співробітників. Обтрунтовані висновки, щзо прочесами лояльності можна управляти з метою досягнення оптимального рівня плинності кадрів на підприємстві.

Ключові слова: лояльність, внутрішній маркетинг, типи лояльності, комплекс маркетингу, афективна лояльність, поведінкова лояльность, програма лояльности персоналу.

\section{ФОРМИРОВАНИЕ ЛОЯЛЬНОСТИ ПЕРСОНАЛА В УСЛОВИЯХ КОНЦЕПЦИИ ВНУТРЕННЕГО МАРКЕТИНГА}

\author{
Богоявленский О. В., к.э.н., доцент (ХИФ КГТЭУ)
}

В статье представлень результаты исследования состояния лояльности персонала предприятий различных сфер деятельности 2. Харькова, определеньл предприятия с преобладающей стабильностью штата сотрудников, выявлень ключевые факторы, которые способствуют продолжительной работе сотрудников на одном месте. Проведен критический анализ различных определений понятия «лояльность персонала». Предложена собственная трактовка классификации типов лояльности. Даны определения основных типов лояльности сотрудников. Проанализированы теоретико-методологические подходы по оценке потенцииальной лояльности работников и кандидатов на вакантные рабочие места. Разработань предложения по осуществлению программ лояльности персонала в рамках системы внутреннего маркетинга. Рассмотрены основные элементы и особенности комплекса внутреннего маркетинга предприятия и его сотрудников. Сделаны выводы, что процессами лояльности можно управлять для достижения оптимального уровня текучести кадров на предприятии.

Ключевье слова: лояльность, внутренний маркетинг, типь лояльности, комплекс маркетинга, аффективная лояльность, поведенческая лояльность, программа лояльности персонала. 


\section{FORMATION OF EMPLOYEE LOYALTY USING THE CONCEPT OF INTERNAL MARKETING}

\section{Bogoyavlensky O.V., PhD, Associate Professor ( Kharkiv Institute of Finance Kyiv National University of Trade and Economics)}

The article presents the results of the research on staff loyalty in organizations of various industries in Kharkiv, defines organizations with generally stable workforce, determines key factors, which contribute to longer employee commitment. A critical analysis has been conducted of different definitions of the concept "staff loyalty». It suggests its own way of classifying types of loyalty. Definitions have been given of main types of employee loyalty. Theoretical and methodological means of measuring potential loyalty of employees and job candidates have been analyzed. Recommendations have been developed for setting up employee loyalty programmes within the internal marketing mix framework. Key elements and features of internal marketing of an organization and its staff have been examined. It has been concluded that the loyalty can be managed to achieve an optimal level of staff turnover in an organization.

Keywords: Loyalty, internal marketing, types of loyalty, marketing mix, affective loyalty, behavioral loyalty, employee loyalty programme.

Постановка проблеми. Скрутні умови діяльності вітчизняних підприємств змушують їх керівництво приймати антикризові програми забезпечення свого виживання. Одним 3 найбільш поширених підходів до проблеми в цей період стає скорочення чисельності персоналу або зменшення оплати праці. Але існують інші альтернативні рішення - залучення колективу до співпраці у подоланні кризових явищ, генерація ідей для розвитку бізнесу та ресурсозбереження. Колектив будь-якого підприємства не може бути однорідним, працівники мають різні цілі та мотиви роботи, погляди на майбутнє та відношення до керівництва та його програм. Менеджерам підприємств важливо знати відношення колективу до організаційних, економічних та технологічних змін для того, щоб своєчасно провести кадрові перестановки. Додатково ситуація ускладняється тим, що робітники підприємства не завжди можуть свідомо оцінити своє ставлення до діяльності керівництва, його програм та рішень.
Ситуація на ринку праці на перший погляд може виглядати сприятливою для пошуку нових співробітників 3 метою заміни старим, які нездатні адаптуватись до нових умов праці (зростання безробіття, наявність великої кількості молоді після закінчення навчальних закладів). Але підбір нових працівників потребує значних зусиль та витрат. У багатьох випадках збереження кваліфікованого співробітника більш ефективне для організації, ніж адаптація та підготовка нового.

Серед тенденцій, які були поміченими дослідниками проблеми підбору персоналу, визначена спрямованість роботодавців до пошуку лояльних працівників. При чому дуже поширеним є перевага лояльності перед професіоналізмом [ 8].

Тому актуальним завданням на сьогодні $є$ створення методичних рекомендацій 3 відбору потенційних працівників, які спроможні на довгострокову і взаємовигідну співпрацю 3 керівництвом підприємства.

Аналіз останніх досліджень i публікацій. Питання формування

Вісник економіки транспорту і промисловості № 59, 2017 
лояльності як одного 3 найважливіших факторів впливу на якість праці персоналу та зменшення збитків від втрати важливих працівників підприємства досліджувались вітчизняними і закордонними вченими та практиками. Сутність i значення лояльності персоналу розглянуто у працях Л. Терстоуна [17], Г. Деслера [2 ], Ф.Райхельда , М. О’Мейлі , В. Доминяка [3], К. Харського[11], І.В. Шпекторенко [12], І.В. Федотової [10 ], Д. Мейєра [14]. К.В. Харський [11], С.С. Баранська [1], Л.Г. Почебут [8] та Л.Терстоун [17], створили методологічні підходи до вимірювання лояльності персоналу. O’Мейлі, Н. Майкл запропонували підходи до створення програм лояльності на підприємстві. В роботах В. Доминяка [3], Т.В. Позднякової Л.П. [6], А. Ференхайма та Д. Тейлора аналізується досвід використання окремих методів оцінки лояльності та наслідки впровадження програм лояльності для організацій.

Але до сих пір не сформований єдиний підхід до класифікації типів і ознак лояльності та окремих факторів іiі створення, які б враховували суттєві розбіжності між різними категоріями персоналу. Практично відсутні роботи присвячені прогнозуванню стану лояльності підприємством та вимірювання потенційної лояльності кандидатів на вакантні посади в організації.

Метою статті $\epsilon$ аналіз методологічних підходів до оцінки та прогнозування окремих типів лояльності на підприємстві та використання окремих різновидів програм лояльності персоналу.

Виклад основного матеріалу. Лояльність персоналу звичайно означає його вірність організації. В англомовних джерелах найбільш частіше використовуються терміни «organizational commitment» i «employee loyalty», але між ними не існує суттєвих розбіжностей.

Критичний аналіз літературних джерел дозволив визначити декілька ключових

ознак

лояльності

співробітників.

1. Доміняк B.I. [3] та Магура M.I. [5] під лояльністю персоналу розуміють додержування норм, правил поведінки, корпоративної культури, цінностей, традицій компанії.

2. Рибачук Н.В. та Журко Т.О. [9] вважають, що лояльність до компанії означає тільки бажання працювати в ній.

3. Баранська С.C. [1] характеризує лояльність співробітників як «емоціональний компонент поведінки».

4. Позднякова Т.В. [6] на перше місце серед проявів лояльності працівника ставить « відсутність намірів звільнення 3 організації».

5. Найбільш повно лояльність персоналу визначають Мейер Д. та Аллен H. [14] які визначають іiї як «психологічний зв'язок між працівниками і організацією, який зменшує вірогідність того, що працівник добровільно залишить організацію».

Таким чином, лояльність персоналу формується у результаті поведінки персоналу і керівництва компанії. Ї̈ можна розглядати як результат взаємного пристосування бажань, вимог i можливостей різних учасників цього процесу. Серед них можна виділити власників компанії, менеджерів різних ланок, самих працівників та стану ринку праці.

3 метою оцінки стану лояльності персоналу були проведені дослідження на 100 підприємствах м. Харкова різних сфер діяльності: освіта, охорона здоров'я, промисловість, торгівля і сфера послуг. Результати оцінки структури персоналу за стажем праці в організації наведені у табл. 1.

Дослідження дозволяють зробити висновки, що проблеми лояльності найбільш невирішені у торговельних підприємствах та організаціях сфери послуг. Частково невирішеними проблеми лояльності залишаються серед 
промислових підприємств для робочих професій.

Більш детально розглянувши фактори, що сприяють лояльності до організації, на тих підприємствах, які досліджувались, можна зазначити.

\section{Таблиия 1}

Розподіл персоналу за стажем роботи в організації [складено автором за результатами власного дослідження]

\begin{tabular}{|l|r|r|r|r|r|}
\hline $\begin{array}{c}\text { Відсоток } \\
\text { співробітників, } \\
\text { які мають стаж }\end{array}$ & $\begin{array}{c}\text { Вищі та } \\
\text { середні } \\
\text { навчальні } \\
\text { заклади }\end{array}$ & $\begin{array}{c}\text { Лікарні, } \\
\text { поліклініки, } \\
\text { санаторії }\end{array}$ & $\begin{array}{c}\text { Офісні } \\
\text { працівники }\end{array}$ & $\begin{array}{c}\text { Робітничі } \\
\text { професії }\end{array}$ & $\begin{array}{c}\text { Торговельні } \\
\text { організації }\end{array}$ \\
\hline До 3 років & 8,3 & 2,4 & 35,2 & 11, & 42,3 \\
\hline Від 3 до 5 років & 15,6 & 8,1 & 26,4 & 5 & 35,4 \\
\hline 5-10 років & 26,4 & 14,7 & 28,1 & 6 & 19,7 \\
\hline $10-20$ років & 28,7 & 32,4 & 9,2 & 25, & 1,9 \\
\hline Понад 20 років & 21,0 & 42,4 & 1,1 & 29, & 0,7 \\
\hline
\end{tabular}

1. На підприємствах сфери освіти та охорони здоров'я працівники витратили значно більше часу на професійну підготовку, ніж у інших сферах діяльності. Їх лояльність скоріше $\epsilon$ лояльністю до професії.

2. Прямої залежності між рівнем оплати праці та лояльності не виявлено.

3. Найбільш суттєвими факторами лояльності працівники вважають перспективи розвитку та стабільності організації, умови праці та соціальні гарантії.

Для аналізу лояльності співробітників в організації пропонується наступна класифікація іiі типів, яка була зроблена на основі праць Терстоуна Л. [17], Баранської С.С. [1], Доминяка В.I. [3] та Поплавської А.П. [7], яка наведена на рис. 1.

Лояльність до організації (організаційна лояльність) розглядається звичайно 3 двох сторін: перший - це благонадійність до підприємства та його бізнесу [4]; другий - це прихильність, прив'язаність до організації [15]. На підприємствах, де існує багато підрозділів, має місце лояльність до свого відділу, департаменту та свого керівника. Дуже поширені ситуації, що у разі переходу керівника на інше місце роботи частина працівників слідують за ним.

Лояльність до професії пов'язана 3 певними обставинами такими, як кваліфікаційний рівень. Наприклад, людина, яка багато років витратила на отримання диплома юриста, ліцензії аудитора або адвоката, наукового звання, не може швидко змінити сферу своєї діяльності.

Причин виникнення багато. Раціональні мотиви утворюють «когнітивну лояльність», яка $\epsilon$ результатом логічного осмислювання інформації про свою роботу в конкретній організації. Працівник усвідомлює, що йому потрібно чи непотрібно зберігати до організації чи професії лояльність та він може це пояснити. 
Афективна

(перцептивна) лояльність спричинена емоціональними мотивами людини. До них відносяться особисті стосунки, імідж організації. Цей тип лояльності притаманний людям, які поділяють цілі і принципи корпоративної культури організації або побоюються опинитися в іншому середовищі у разі зміни місця роботи.

\begin{tabular}{|c|c|}
\hline \multicolumn{2}{|c|}{ Лояльність персоналу } \\
\hline За об’єктами лояльності & За причиною виникнення \\
\hline $\begin{array}{l}\text {-до організації (підприємства); } \\
\text {-до мікроколективу (підрозділу); } \\
\text {-до керівника; } \\
\text {-до професії, сфери діяльності. }\end{array}$ & $\begin{array}{l}\text {-когнітивна; } \\
\text {-раціональна (оцінювальна); } \\
\text {-трансакційна; } \\
\text {-конативна: }\end{array}$ \\
\hline За своєю величиною & $\begin{array}{l}\text {-афективна (перцептивна); } \\
\text {-змішана; } \\
\text {-вимушена. }\end{array}$ \\
\hline $\begin{array}{l}\text {-позитивна; } \\
\text {-нейтральна; }\end{array}$ & За своїм проявом \\
\hline -негативна. & $\begin{array}{l}\text {-інтровертна; } \\
\text {-екстравертна; } \\
\text {-пасивна; } \\
\text {-активна. }\end{array}$ \\
\hline
\end{tabular}

Рис. 1. Класифікація типів лояльності [власна розробка]

Конативна лояльність $\epsilon$ поєднання емоційних i раціональних факторів. Звичайно вона виникає, коли людина залучена до вирішення важливих проблем підприємства, які працівник також вважає своїми проблемами. Такий співробітник відчуває, що він зробив багато для організації, має багато планів на майбутнє. У такому разі він не має бажання змінити організацію, у розвиток якої він вклав багато сил.

Транзакційна (поведінкова) лояльність пов'язана зі звичками та стереотипами поведінки. Працівник обирає місце роботи тому, що не бажає змінювати місце життя. Наприклад, відмовляється від переїзду в інше місто або країну. Подібний тип лояльності був притаманний часам соціалізму, коли на деяких великих підприємствах працювали чоловік, жінка та їх діти.

Вимушена лояльність має місце, коли людина не має змоги звільнитися 3 організації, це може бути спричинене тим, що він уклав довгострокову угоду, розірвання якої може призвести до великих фінансових витрат (наприклад, отримав кредит або житло на пільгових умовах). Також вона існує у випадку, коли у працівника не має можливості знайти інше місце роботи.

Під час дослідження лояльності як відношення можна виділити позитивну, негативну та нейтральну лояльність.

Позитивна лояльність проявляється у бажанні підтримувати дії керівництва компанії, сприяти успіху планів, у тому числі таких заходів, які не обов'язково створюють зручності для працівника. 
Нейтральна лояльність характерна для працівників, які байдуже ставляться до справ свого підприємства. Причини можуть бути особисті (характер людини, психологічний клімат) або низька ступінь залучення до планів і прийняття рішень в організації.

Лояльність персоналу близька до поняття «задоволеність», що означає ступінь наближення умов, оплати праці, професійної майстерності, сумлінності працівника до вимог керівників різного рангу та самих виконавців. Але задоволеність не обов'язково означає лояльність та лояльність може існувати без задоволеності у деяких обставинах.

3 1980-х років для впливу на процеси лояльності і задоволеності потреб різних груп персоналу організації почала використовуватись концепція внутрішнього маркетингу, внесок у розвиток якої зробили американські вчені Л. Беррі i А. Парасуранан [ 16] та британські М. Рафік і П.К. Ахмед [13].

Концепція внутрішнього маркетингу значно ширше проблем лояльності персоналу і має три основні аспекти.

1. Філософія взаємовідносин к співробітникам як клієнтами - компанії для отримання від них роботи - продукту.

2. Система мотивації персоналу до інтегрованої праці 3 метою ефективної реалізації корпоративних функціональних стратегій.

3. Система планомірних дій 3 подолання супротиву персоналу до змін та інновацій, ініційованих керівництвом компанії.

4. Клієнтоорієнтованість усіх працівників компанії, для яких будь-яка робота розглядається як процес задоволення потреб клієнтів. У якості клієнтів виступають як споживачі продукції компанії та працівники різних підрозділів.

Внутрішній маркетинг вміщує у собі традиційні для «класичного маркетингу» поняття як «комплекс маркетингу» у вигляді 4 «Р» (product, price, place, promotion).

Продукт - це робота, яку виконує працівник для організації, клієнтом продукту виступає керівництво компанії та її зовнішні споживачі. Але з точки зору працівника компанії то продукт це умови праці, характер роботи, статус, обов'язки які йому пропонує працедавець.

Ціна продукту - це форми заробітної плати, преміювання, витрати на підвищення кваліфікації робітників, створення умов праці, соціальні пакети, транспортні витрати, тощо.

Місце - це організаційні компоненти, які забезпечують процес взаємного задоволення потреб працівника i працедавця. До них належить оптимальність системи управління в організації, його організаційна структура, організація праці і виробництва, графік роботи, відрядження тощо.

Просування

(комунікаційна політика) - це побудова системи ефективних взаємовідносин між різними ланками системи управління підприємства, розвиток внутрішнього PR, створення певних правил поведінки, звичок усіх працівників організації та системи цінностей, яку поділяють усі, хто працює в організації та мають 3 нею справу.

Внутрішній маркетинг вміщує у собі декілька функцій, одна 3 яких аналітична. Основним іiї компонентом $\epsilon$ внутрішньофірмове маркетингове дослідження, яке проводиться 3 метою з'ясування ступеню задоволеності i лояльності працівників компанії, як «продуктами» інших підрозділів та колег по роботі свого підрозділу, так і роботою своєї компанії і ії керівництвом.

Внутрішній маркетинг представляє собою процес взаємодії комплексу маркетингу працедавця та комплексу маркетингу працівника організації. У залежності від кваліфікації, цінності для організації та незамінності він створює свій маркетинг, орієнтований на

Вісник економіки транспорту і промисловості № 59, 2017 
керівників підприємства. До нього входять.

Продукт - це професійні компетентності, фізичні здібності, кваліфікаційні документи (наукове звання, освіта, професійні ліцензіі), вік, стаж.

Ціна - це вимоги до оплати, умов соціального забезпечення, витрат на підвищення кваліфікації.

Місце - це спроможність та готовність виконувати поставлені завдання у відповідних умовах (надомна праця, відрядження, праця в офісі, праця на вулиці, у шкідливих умовах, тощо).

Просування - вміщує у собі імідж працівника (особистий бренд), його біографію, відгуки про його попередню працю, вміння створити позитивні взаємовідносини 3 керівниками, підлеглими, партнерами по бізнесу, клієнтами.

Лояльність i задоволеність персоналу можлива за умови ефективної взаємодії комплексу внутрішнього маркетингу підприємства і маркетингових дій співробітників.

В рамках внутрішнього маркетингу відбувається цілеспрямована діяльність керівництва підприємства і персоналу, які одночасно відіграють роль «продавця» $\mathrm{i}$ «покупця» своїх продуктів.

Організації потрібно від своїх співробітників:

1. виконання планів i завдань $\mathrm{y}$ повному обсязі з дотримання вимог якості і етики;

2. участь у розвитку i удосконаленні діяльності на підприємстві;

3. спроможність переносити складності і незручності у своєї діяльності завдяки успіху організації;

4. причетність до цілей, досягнень і невдач компанії;

5. дотримання норм, правил поведінки, дотримання корпоративних таємниць, ділової культури.

Співробітникам потрібно від підприємства, на якому вони працюють: потреб;

1. забезпечення матеріальних

2. позитивні емоції, моральне задоволення від свого внеску в справи організації;

3. соціальні гарантії, допомога у вирішенні особистих проблем;

4. особистий розвиток, професіональне удосконалювання.

Лояльність в рамках внутрішнього маркетингу можна вважати результатом успішної взаємодії комплексу внутрішнього маркетингу підприємства i особистих комплексів маркетингу співробітників.

Висновки. Лояльність персоналу представляє собою результат взаємодії комплексів маркетингу (маркетингу-мікс) керівництва компанії та особистого комплексу маркетингу працівника, на який впливає зовнішнє маркетингове середовище (стан ринку праці, нормативні вимоги до співробітників, демографічна ситуація в країні, тощо).

Об'єктивне вимірювання лояльності можливе за умови дослідження особистих пріоритетів конкретного працівника.

Лояльністю персоналу до організації можна управляти для підтримання оптимального рівня цього показника за допомогою різних програм лояльності, ефективність яких необхідно оцінювати.

Для прогнозування та вимірювання лояльності працівників необхідна наступна інформація:

1. про задоволеність персоналу, яку можна отримати шляхом соціологічних опитувань;

2. про можливість і складність для працівників знайти інше місце праці або інший вид діяльності;

3. про важливість окремих чинників лояльності для кожного конкретного працівника.

У якості рекомендацій для вибору напрямів подальших досліджень можливе зазначити: проведення аналізу впливу

Вісник економіки транспорту і промисловості № 59, 2017 
соціально-демографічних характеристик працівників i факторів зовнішнього середовища на лояльність персоналу та розробка методів оцінки ефективності програм лояльності в системі внутрішнього маркетингу підприємства.

\section{ПЕРЕЛІК ВИКОРИСТАНИХ ДЖЕРЕЛ}

1. Баранская C.C. Методика измерения лояльности [Электронный pecypc].- С.C. Баранская //Психологические исследования. - 2011.Вып. 1(45). - Режим доступу http://psystudy.ru/index.php/num/2011n115/436-baranskaya15.html.

2. Десслер Г. Управление персоналом [Електронный ресурс] / Г. Десслер. - Пер. с англ. - 2-е изд. (эл.). - М. : БИНОМ. Лаборатория знаний, 2013. - 799 с. : - Режим доступу http://files.pilotlz.ru/pdf/cC2305-0-ch.pdf

3. Доминяк В. Как предсказать организационную лояльность: модель оценки // Управление персоналом, 2006, №13 - c. 62-68.

4. Ковров А.В. Лояльность персонала: оценка надежности персонала. Проблемы наемного работника. Как выявить опасные типы / А.В. Ковров. М.: Бератор, 2004. - 165 c.

5. Магура М.И., Курбатова М.Б. «Современные персонал-технологии». Глава 9. Организационная приверженность // Управление персоналом, №6 (60), 2001, с. 45-50.

6. Позднякова Т.В. Лояльность персонала организаций: анализ теоретикометодологических методических аспектов ресурс]. - Режим доступу : https://pnojournal.files.wordpress.com/2013/ 01/pdf_130210.pdf

7. Поплавська А.П. Психологічний аналіз видів лояльності персоналу до організації. - Режим доступу : http://sites.znu.edu.ua/sppconf/2013pdf/ poplavskaya_3.pdf
8. Почебут Л.Г. Оценка лояльности сотрудника к организации. // Практикум по психологии менеджмента и профессиональной деятельности / Под ред. Г.С. Никифорова, М.А. Дмитриевой, В.М. Снеткова. - СПб: Речь, 2001, с.283287.

9. Рибачук Н.В., Журко Т.О. Формування лояльності працівників піпідприємства як важливого чинника його функціонування [Електронний ресурс]. Режим доступу: http://rybachuk.vk.vntu.edu.ua/file/104f4f82f 16b0a88f8c1f299963de889.pdf

10. Федотова I.В. Оцінювання рівня лояльності персоналу підприємства. - Режим доступу : http://dspace.khadi.kharkov.ua/dspace/handle /123456789/903

11. Харский К. Благонадежность и лояльность персонала / К. Харский. - СПб. : Питер, 2003. - 496 с.

12. Шпекторенко І.В. Лояльність як якість персоналу: до проблеми формування та оцінювання [Електронний ресурс]- Режим доступу http://www.dridu.dp.ua/zbirnik/201301(9)/13sivpfo.pdf

13. Ahmed, P. K., Rafiq, M., 2003. Internal marketing issues and challenges, European Journal of Marketing, 37(9), 1177-1186.

14. Meyer and Allen Model of Organizational Commitment: Measurement Issues [Електронний pecypc], The Icfai Journal of Organizational Behavior, Vol. VI, No. 4, 2007 - Режим доступу : http://stevejaros.com/wpcontent/uploads/2009/08/Jaros-ICFAI-2007Meyer-and-Allen1.pdf.

15. Allen $\mathrm{N} J$ and Meyer $\mathrm{J} P$ (1990), «The Measurement and Antecedents of Affective, Continuance and Normative Commitment to the Organization», Journal of Occupational Psychology, Vol. 63, pp. 1-18.

16. Leonard L. Berry, A. Parasuraman Marketing Services: Competing Through Quality New York: The Free Press, 1991. - 228 p. 
17. Louis Leon Thurstone. Режим доступу: https://brocku.ca/ «Theory of Attitude Measurement». MeadProject/Thurstone/Thurstone_1929b.ht Psychological Review 36 (1929): 222-241. - ml

УДК 656.071.3(477)

\title{
ТЕОРЕТИЧНІ ПІДХОДИ ДО ДЕРЖАВНОГО УПРАВЛІННЯ І АДМІНІСТРУВАННЯ ЗАЛІЗНИЧНОГО ТРАНСПОРТУ УКРАЇНИ
}

\author{
Дейнека О.Г., д.е.н., професор,
}

Каплієнко А.Л., магістрант програми ТЕМПУС (УкрДУЗТ)

В статті розглянуто теоретичні та методичні підходи до державного управління і адміністрування залізничного транспорту України. Покреслено значучість залізничного транспорту як природної монополії, проаналізовані підходи до єдності иілей управління. Проведений систематичний аналіз праць з державного регулювання управління $i$ адміністрування. Виділені змістовні характеристики залізничного транспорту та функиї державного регулювання, управління $i$ адміністрування. Розкриті наукові підходи до розв'язування конкретних задач ПАТ «Украӥнська залізниия».

Ключові слова: публічне управління $\boldsymbol{i}$ адміністрування , державне регулювання транспорту, механізм державного регулювання, організаційний механізм.

\section{ТЕОРЕТИЧЕСКИЕ ПОДХОДЫ К ГОСУДАРСТВЕННОМУ УПРАВЛЕНИЮ И АДМИНИСТРИРОВАНИЮ ЖЕЛЕЗНОДОРОЖНЕГО ТРАНСПОРТА УКРАИНЫ}

\author{
Дейнека О.Г., д.э.н., профессор, \\ Каплиенко А.Л., магистрант программы ТЕМПУС (УкрГУЖТ)
}

B cтатье рассмотрень теоретические $u$ методические подходы $\kappa$ государственному управлению и администрированию железнодорожного транспорта Украины. Подчеркнуто значение железнодорожного транспорта как естественной монополии, проанализированы подходы к единству целей управления. Проведенн анализ трудов по государственному регулированию управлению и администрированию. Выделены содержательные характеристики железнодорожного транспорта и функции государственного регулирования, управления и администрирования .Раскрыты научные подходы к решению конкретных задач ПАО «Украинская зализныцяя.

Ключевые слова: публичное управление и администрирование, государственное регулирование транспорта, механизм государственного регулирования, организационный механизм.

(C) Дейнека О.Г., Каплієнко А.Л.
Вісник економіки транспорту і промисловості № 59, 2017 